\title{
Effects of Mixed Organic and Inorganic Fertilizers Application on Soil Properties and the Growth of Kenaf (Hibiscus cannabinus L.) Cultivated on Bris Soils
}

\author{
${ }^{1}$ Mohd Hadi Akbar Basri, ${ }^{1,2}$ Arifin Abdu, ${ }^{3}$ Shamshuddin Jusop, \\ ${ }^{4}$ Osumanu Haruna Ahmed, ${ }^{1,2}$ Hazandy Abdul-Hamid, ${ }^{1,2}$ Mohd-Ashadie Kusno, \\ ${ }^{2}$ Baharom Zainal, ${ }^{1,2}$ Abdul Latib Senin and ${ }^{2}$ Nasima Junejo \\ ${ }^{1}$ Department of Forest Management, Faculty of Forestry, \\ ${ }^{2}$ Institute of Tropical Forestry and Forest Products, \\ ${ }^{3}$ Department of Land Management, Faculty of Agriculture, \\ University Putra Malaysia, 43400 UPM Serdang, Selangor, Malaysia \\ ${ }^{4}$ Department of Crop Science, University Putra Malaysia, Bintulu Campus Sarawak, Malaysia
}

Received 2013-08-02, Revised 2013-09-19; Accepted 2013-10-28

\begin{abstract}
The demand for kenaf in the world increases rapidly by the years. Cultivation of the crop in Malaysia is a challenging task, especially when kenaf is grown on sandy soils with low fertility, such as the BRIS Soils (Beach Ridges Interspersed with Swales). A pot study was conducted in a glasshouse at Universiti Putra Malaysia to evaluate the potential of inorganic and organic fertilizers or their combination for growing kenaf on very sandy BRIS Soils, using variety V36. There were altogether sixteen treatments: $\left(\mathrm{T}_{1}\right)$-control $(100 \%$ BRIS soil), ( $\left.\mathrm{T}_{2}\right)$-NPK (chemical fertilizer), ( $\left.\mathrm{T}_{3}\right)$-CM (chicken manure), $\left(\mathrm{T}_{4}\right)-\mathrm{B}$ (biochar), $\left(\mathrm{T}_{5}\right)-\mathrm{Z}$ (zeolite), $\left(\mathrm{T}_{6}\right)-\mathrm{NPK}+\mathrm{CM}, \quad\left(\mathrm{T}_{7}\right)-\mathrm{NPK}+\mathrm{B}, \quad\left(\mathrm{T}_{8}\right)-\mathrm{NPK}+\mathrm{Z}, \quad\left(\mathrm{T}_{9}\right)-\mathrm{CM}+\mathrm{B}, \quad\left(\mathrm{T}_{10}\right)-\mathrm{CM}+\mathrm{Z}, \quad\left(\mathrm{T}_{11}\right)-\mathrm{B}+\mathrm{Z}, \quad\left(\mathrm{T}_{12}\right)-\mathrm{NPK}+\mathrm{CM}+\mathrm{B}$, $\left(\mathrm{T}_{13}\right)-\mathrm{NPK}+\mathrm{CM}+\mathrm{Z}, \quad\left(\mathrm{T}_{14}\right)-\mathrm{CM}+\mathrm{B}+\mathrm{Z}, \quad\left(\mathrm{T}_{15}\right)-\mathrm{NPK}+\mathrm{B}+\mathrm{Z}$ and $\left(\mathrm{T}_{16}\right)-\mathrm{NPK}+\mathrm{CM}+\mathrm{B}+\mathrm{Z}$. Results showed that application of inorganic material or organic fertilizer in combination with chemical fertilizer $\left(\mathrm{T}_{2}\right.$ and $\left.\mathrm{T}_{16}\right)$ improved soil fertility, which are reflected by the increase inexchangeable $\mathrm{K}, \mathrm{Ca}$ and $\mathrm{Mg}, \mathrm{CEC}$, total $\mathrm{N}$, total $\mathrm{C}$ and available $\mathrm{P}$. The highest kenaf growth was observed in $\mathrm{T}_{15}$ treatment.Application of biochar, zeolite or chicken manure alone on the soils did not result in better kenaf growth compared to the control. Zeolite and biochar should be applied with other fertilizers or organic substrate to obtain a positive yield of crop and increase the soil properties. In addition, more studies on the application of chicken manure at different ratios should be conducted to obtain the best yield. Combination treatment, $\mathrm{T}_{15}(\mathrm{NPK}+$ biochar + zeolite) can be suggested to the farmers especially cultivation of kenaf on sandy BRIS soil in order to obtain the best kenaf growth performance and indirectly reduce excessive use of chemical fertilizers.
\end{abstract}

Keywords: Biochar, BRIS Soils, Chicken Manure, Kenaf, Zeolite

\section{INTRODUCTION}

Kenaf (Hibiscus cannabinus L.) is a warm-season annual crop that is similar tocotton, okra and Hibiscus. It can reach the height of 2 to $6 \mathrm{~m}$ and is harvested for their stalks from which the fiber is extracted (Preston, 2003). Kenaf is native to EastCentral Africa and all over South America-Asia. It is utilized in the cordage and sacking manufacture as a substitute of jute and more recently as a raw material for the production of paper pulp (Abdul-Hamid et al., 2009).

Corresponding Author: Arifin Abdu, Department of Forest Management, Faculty of Forestry, University Putra Malaysia, 43400 UPM Serdang, Selangor, Malaysia 
In Malaysia, Kenaf is normally planted on sandy BRIS Soils due to its ability to adapt to adverse environmental conditions, such as low soil fertility. BRIS Soils are located along the coastal plains of Peninsular Malaysia and Sabah with an approximate area of 200,000 ha (Abdul-Hamid et al., 2009). They contain up to $82-99 \%$ sand particles with cation exchange capacity of $9.53 \mathrm{cmol}_{\mathrm{c}} \mathrm{kg}^{-1}$ soil and the soil reaction is usually acidic (Chen, 1985; Roslan et al., 2010). Because of high surface soil temperature, low water holding capacity, low organic content, high infiltration rate and low nutrients availability, most of the crops planted on BRIS Soils do not perform well (Hanafi et al., 2010). Lack of moisture and low nutrient retention are the main limitations for crop production on BRIS Soils.

There are some fertilizers and soil amendments that are able to improve the fertility of BRIS Soils. Biochar or charcoal is one of the potential soil amendments that can be used to improve the productivity of these problematic soils. Biochar is produced from combustion of plant residues and it contains stable carbon that is able to remain for a long period of time in soil (Major et al., 2010). Addition of biochar into the soils would increase plant nutrients, resulting in improved soil fertility (Lehmann et al., 2003; Rondon et al., 2007). Steiner et al. (2008) found that application of biochar amended with fertilizer increased crop yield.

Utilization of chicken manure as an organic fertilizer nowadays has been increasing dramatically especially in improving soil productivity and crop production. Chicken manure is believed to be able to supply many plant nutrients to soils. Study carried by Dikinya and Mufwanzala (2010) showed that soil fertility can be enhanced by chicken dung application by way of increasing exchangeable bases in the soils. Furthermore, other nutrients such as nitrogen and phosphorus can be increased. Chicken manure is one of the preferred organic fertilizers because of the high content of macronutrients in it (Warman, 1986; Duncan, 2005).

Zeolite is derived from volcanic ash and is sometimes used as a soil conditioner to improve soil fertility. It has high cation exchange capacity and therefore can reduce nutrient loss via leaching during rainy season (Mumpton, 1999; Glisig et al., 2008; Hecl and Toth, 2009). Its high $\mathrm{CEC}$ is also able to reduce ammonia volatilization and increase the affinity of ammonium ions binding (Ming and Dixon, 1986). Nutrient uptake efficiency of crops can be enhanced by applying urea in combination with zeolite (Ahmed et al., 2008). In addition, available nutrients in the soils can be retained at much longer time. This study was undertaken to determine the effects of mixed organicinorganic fertilizer application on the properties of BRIS Soils and the growth of Hibiscus cannabinus $\mathrm{L}$.

\section{MATERIALS AND METHODS}

\subsection{Study Site and the Soil Used}

A study was conducted at the Controlled Environment Structure, No. 2(CES 2), Agrotech Agriculture Complex, University Putra Malaysia, Serdang, ( $2^{\circ} 58^{\prime} 54^{\prime}$ N, $101^{\circ}$ 42 '51" E) for a period of four months (January to April 2012). The minimum and maximum temperatures recorded during the study period inside the glasshouse were $23^{\circ} \mathrm{C}$ and $38^{\circ} \mathrm{C}$, respectively. The soil used in this experiment was Baging Series, taxonomically classified as sandy, siliceous family of Typic Quartzipsamments, containing $88.68 \%$ sand, $4.68 \%$ silt and $6.64 \%$ clay. This soil type is normally located nearest to the coastline and can be found in east coast of Peninsular Malaysia, especially along Kelantan-Terengganu and Borneo Island, Sabah. These coastal plains comprised of many soil series whereas the common can be found are Baging, Rhu Tapai, Rudua and Jambu series (Roslan et al., 2011).

\subsection{Treatments and Experimental Design}

Twenty kilograms of the sandy BRIS Soils was filled in pots of $35 \mathrm{~cm}$ height and $35 \mathrm{~cm}$ diameter. The soils were treated with fertilizers (inorganic and organic), biochar and/or zeolite. The biochar used in this study was derived from oil palm Empty Fruit Bunch (EFB). Processed chicken manure used was in pellet form. Zeolite was added seven days before planting. The composition of zeolite used: $\left(\mathrm{Al}_{2} \mathrm{O}_{3}, 10.42 ; \mathrm{SiO}_{2}, 69.96\right.$; $\mathrm{Fe}_{2} \mathrm{O}_{3}, 1.1 ; \mathrm{TiO}_{2}, 0.17 ; \mathrm{CaO}, 1.36 ; \mathrm{MgO}, 0.56 ; \mathrm{K}_{2} \mathrm{O}$, $\left.2.52 ; \mathrm{Na}_{2} \mathrm{O}, 0.31 ; \mathrm{MnO}, 0.02 ; \mathrm{Cr}_{2} \mathrm{O}_{3}, 2.52 \%\right)$ and (CEC, $171.74 \mathrm{cmol}_{\mathrm{c}} \mathrm{kg}^{-1}$ soil). Rate of NPK used was as recommended by National Kenaf and Tobacco Board for BRIS Soils management, which was applied twice (before and after planting). There were altogether sixteen treatments: $\left(\mathrm{T}_{1}\right)$-control $(100 \%$ BRIS soil $),\left(\mathrm{T}_{2}\right)-\mathrm{NPK}$ (chemical fertilizer), $\left(\mathrm{T}_{3}\right)-\mathrm{CM}$ (chicken manure), $\left(\mathrm{T}_{4}\right)-$ $\mathrm{B}$ (biochar), $\left(\mathrm{T}_{5}\right)-\mathrm{Z}$ (zeolite), $\left(\mathrm{T}_{6}\right)-\mathrm{NPK}+\mathrm{CM},\left(\mathrm{T}_{7}\right)-$ $\mathrm{NPK}+\mathrm{B},\left(\mathrm{T}_{8}\right)-\mathrm{NPK}+\mathrm{Z},\left(\mathrm{T}_{9}\right)-\mathrm{CM}+\mathrm{B},\left(\mathrm{T}_{10}\right)-\mathrm{CD}+\mathrm{Z},\left(\mathrm{T}_{11}\right)-$ $\mathrm{B}+\mathrm{Z},\left(\mathrm{T}_{12}\right)-\mathrm{NPK}+\mathrm{CM}+\mathrm{B},\left(\mathrm{T}_{13}\right)-\mathrm{NPK}+\mathrm{CM}+\mathrm{Z},\left(\mathrm{T}_{14}\right)-$ $\mathrm{CM}+\mathrm{B}+\mathrm{Z},\left(\mathrm{T}_{15}\right)-\mathrm{NPK}+\mathrm{B}+\mathrm{Z}$ and $\left(\mathrm{T}_{16}\right)-\mathrm{NPK}+\mathrm{CM}+\mathrm{B}+\mathrm{Z}$ were established in this experiment, with six replications for each treatment (Table 1). Biochar and chicken manure were applied at the rate of $1000 \mathrm{~kg} / \mathrm{ha}$, respectively and scaled down to per pot basis equivalent to $100 \mathrm{~g}$. Zeolite was applied at $80 \mathrm{~g}$ per pot. NPK fertilizer was applied at the rate of $100 \mathrm{~kg} / \mathrm{ha}$ for N, 100 $\mathrm{kg} / \mathrm{ha}$ for $\mathrm{P}_{2} \mathrm{O}_{5}$ and $100 \mathrm{~kg} /$ ha for $\mathrm{K}_{2} \mathrm{O}$. The NPK fertilizer was scaled down to per pot basis equivalent to $1 \mathrm{~g}$ urea, $2 \mathrm{~g}$ TSP and $1 \mathrm{~g}$ of MOP. 
Table 1. Label and details of the treatment used in the study

\begin{tabular}{ll}
\hline Treatment & Description \\
\hline $\mathrm{T}_{1}$ & Control (100\% BRIS soil) \\
$\mathrm{T}_{2}$ & Soil + NPK \\
$\mathrm{T}_{3}$ & Soil + Chicken manure \\
$\mathrm{T}_{4}$ & Soil + Biochar \\
$\mathrm{T}_{5}$ & Soil + Zeolite \\
$\mathrm{T}_{6}$ & Soil + NPK + Chicken manure \\
$\mathrm{T}_{7}$ & Soil + NPK + Biochar \\
$\mathrm{T}_{8}$ & Soil + NPK + Zeolite \\
$\mathrm{T}_{9}$ & Soil + Chicken manure + Biochar \\
$\mathrm{T}_{10}$ & Soil + Chicken manure + Zeolite \\
$\mathrm{T}_{11}$ & Soil + Biochar + Zeolite \\
$\mathrm{T}_{12}$ & Soil + NPK + Chicken manure + Biochar \\
$\mathrm{T}_{13}$ & Soil + NPK + Chicken manure + Zeolite \\
$\mathrm{T}_{14}$ & Soil + Chicken manure + Biochar + Zeolite \\
$\mathrm{T}_{15}$ & Soil + NPK + Biochar + Zeolite \\
$\mathrm{T}_{16}$ & Soil + NPK + Chicken manure + Biochar + Zeolite \\
\hline
\end{tabular}

Note: $\mathrm{T}=$ Treatment, NPK $=$ Nitrogen, Phosphorus, potassium (chemical fertilizer)

For NPK application, it was applied two times: 3 days before planting and 30 days after planting. The experimental design was Completely Randomized Design (CRD).

\subsection{Kenaf Seedlings}

Kenaf seedlings, variety V36, were used in the study. This is the variety recommended by the National Kenaf and Tobacco Board for growing on infertile soils. Seven kenaf seeds were planted at $0.5 \mathrm{~cm}$ depth and the seedlings were thinned down to three plants per pot during the germination stage.

\subsection{Soil Sampling and Analyses}

Soil samples were collected randomly from three points in each pot $(0-15 \mathrm{~cm}$ depth), before planting and after harvesting. The soils were mixed uniformly to form a composite sample and air-dried for 24 fours, followed by sieving through a $\leq 2.0 \mathrm{~mm}$ sieve and kept in polyethylene bags for further analysis in the laboratory. The selected soil physico-chemical properties determined were texture, $\mathrm{pH}$, exchangeable cations (K, $\mathrm{Na}, \mathrm{Mg}, \mathrm{Ca}$ ), exchangeable $\mathrm{Al}$, exchangeable ammonium $\left(\mathrm{NH}_{4}^{+}\right)$, Nitrate $\left(\mathrm{NO}_{3}^{-}\right)$, available $\mathrm{P}$, cation exchange capacity, total $\mathrm{N}$ and total $\mathrm{C}$. Soil texture was determined by the pipette method of Day (1965). Total N and $\mathrm{C}$ and were analyzed by dry combustion method using LECO CHNanalyzer (model VICNS Tru Mac Analyzer). $\mathrm{pHKCl}$ and $\mathrm{pH}$ water of the soils were measured with a glass electrode at soil: $\mathrm{KCl} /$ water ratio of 1:5 (Jones, 2001). Exchangeable bases (K, Ca, Mg and $\mathrm{Na}$ ) and Cation Exchange Capacity (CEC) were determined by the leaching method with ammonium acetatesolution $\left(\mathrm{NH}_{4} \mathrm{OA}_{\mathrm{c}}\right.$ ) buffered at $\mathrm{pH} 7$ (Lavkulich, 1981). The concentration of exchangeable bases was then analyzed using Atomic Absorption Spectrophotometer (AAS), model Shimadzu AA- 6800. Available $\mathrm{P}$ was determined by Bray and Kurtz procedure no. 2 (Bray and Kurtz, 1945) and the concentrations were analyzed using Auto analyzer. Exchangeable acidity and exchangeable aluminum were extracted by $1 \mathrm{MKCl}$. The exchangeable acidity was determined by the titration method using $0.01 \mathrm{M}$ $\mathrm{NaOH}$ and the concentration of $\mathrm{Al}$ using $0.01 \mathrm{M} \mathrm{HCl}$ (Sumner and Stewart, 1992). Exchangeable ammonium and nitrate were extracted from the soil samples using $2 \mathrm{M} \mathrm{KCl}$, followed by steam distillation method (Keeney and Nelson, 1982).

\subsection{Measurement on Growth Performance of Kenaf}

Height, diameter and the number of kenaf leaves were taken and recorded every month for a period of 16 weeks. Plant height was measured using a stainless steel ruler and height pole was used when the height reached 1 $\mathrm{m}$ and above. The height was measured from cotyledon level up to the base at the terminal bud. The diameter of the plant was measured at $10 \mathrm{~cm}$ above the ground using a digital caliper (Model Mitutoyo $200 \mathrm{~mm}$ ). Two readings were recorded at the stem for diameter and marked using a permanent marker pen. Total number of leaves for each plant was calculated manually and the data were recorded.

\subsection{Statistical Analysis}

Growth parameter of different kenaf parts and soil parameters were analyzed using Analyses of Variance (ANOVA), followed by Duncan's Multiple Range Test Test (DMRT) to detect the significant difference among the treatments (SAS, 2001).

\section{RESULTS AND DISCUSSION}

\subsection{Initial Properties of the Soil}

The physico-chemical properties of the soil before amending with fertilizersare presented in Table 2. The soil texture was mainly loamy sand $(84.14 \%$ sand, $6.37 \%$ silt and $9.33 \%$ clay) and the $\mathrm{pH} \mathrm{KCl}$ and $\mathrm{pH}$ water was 4.20 and 3.14, respectively. The exchangeable bases (K, $\mathrm{Ca}, \mathrm{Mg}, \mathrm{Na}$ ) were low, with a range between 0.174 and $0.311 \mathrm{cmol}_{\mathrm{c}} \mathrm{kg}^{-1}$. The low exchangeable bases were related to the sandy nature of the soils. Previous studies conducted by Toriman et al. (2009) reported that due to the sandy structure of the soil, the contents of bases in 
BRIS soil such as phosphorus, potassium, magnesium and calcium were relatively low. The CEC recorded in this study was very low with a value of $3.94 \mathrm{cmol}_{\mathrm{c}} \mathrm{kg}^{-1}$ soil which was due to low clay content and similar to other study found by (Malisa et al., 2011; Roslan et al., 2011) reported that the CEC values on a BRIS soil less than $5 \mathrm{cmol}_{\mathrm{c}} \mathrm{kg}^{-1}$. This means that the bases are easily lost via leaching during rainy season. This is similar to Akbar et al. (2010) who reported that different in CEC values due to soil erosion or leaching. Parfitt et al. (1995) also reported that lower contents of clay and loam in the soil lead to a low CEC values. Other researchers also found that the CEC of soils in tropics were affected by different negative charges derived from clay minerals and due to the amount of clay in soil (Ohta and Effendi, 1992; Hamzah et al., 2009; Saga et al., 2010; Zaidey et al., 2010; Sakurai et al., 1998; Arifin et al., 2008; Roslan et al., 2011). Total N and total C were also low and hence these soils are considered as very poor. Previous studies also found that essential nutrient such as total $\mathrm{N}$ and total $\mathrm{C}$ in BRIS soil are relatively low (Malisa et al., 2011). Study conducted by Dharejo et al. (2012) who reported that the total $\mathrm{N}$ content in the BRIS soil was in range of $0.01-0.03 \%$ and similar reported to the present study.

\subsection{Soil Properties at Harvest}

There were significant differences detected between the control $\left(T_{1}\right)$ and other treatments at $p \leq 0.05$ which prove that addition of organic and inorganic fertilizers improved the soil fertility (Table 2). The soil $\mathrm{pH}$ in water and $\mathrm{KCl}$ was nearly neutral. The highest value of $\mathrm{pH}$ was observed for $\mathrm{T}_{10}$ treatment with the respective value of 6.82 and 6.45 . Chicken manure has an ability to increase acidic soils. The high $\mathrm{pH}$ value in this treatment was due the effect of chicken manure which contained calcium carbonate (Camberato and Mitchell, 2011). The lowest $\mathrm{pH}$ was recorded in $\mathrm{T}_{5}$ treatment with the value of 4.21 in water and 3.82 in $\mathrm{KCl}$. Present study showed that application of zeolite alone without combining with other soil amendment or any fertilizer cannot be expected to increase the BRIS soil chemical properties. In fact, the soil properties are more acidic and almost similar with control treatment. Zeolite should be applied with other fertilizer or soil amendment. Zeolite mixed with nitrogen, phosphorus and and potassium compounds enhances the actions of nutrient compounds as slow-release fertilizers, both in horticultural and extensive crops (Dwairi, 1998). Similar studies reported by Leggo (2000) who suggested that zeolite should be applied with organic substrate.
Total $\mathrm{N}$ varied from 0.03 to 0.14 having the highest value of $0.14 \%$ in $\mathrm{T}_{7}$, followed by $\mathrm{T}_{15}(0.137 \%)$, while the lowest value was recorded in $\mathrm{T}_{1}(0.03 \%)$. Nitrogen, in the form of ammonium, is easily lost via volatilization. Results from this study showed that the loss can be minimized by combining $\mathrm{N}$-fertilizer with biochar $\left(\mathrm{T}_{7}\right)$. This result is similar reported by Zheng et al. (2013), who stated that addition of biochar reduced $\mathrm{N}$ fertilizer demand in crop production due to reduction in $\mathrm{N}$ leaching, hence increase $\mathrm{N}$ use efficiency for agricultural purposes. Taghizadeh-Toshi et al. (2012) also reported that addition of biochar may influence $\mathrm{N}$ bioavailability and alter bioavailability of other nutrients for plant uptake. This agreed with the concept that $\mathrm{N}$ is an essential nutrient in supporting plant growth, physiology and carbohydrate content (Terbe, 2004; Almodeares et al., 2008).

Total $\mathrm{C}$ was the highest in $\mathrm{T}_{4}$ treatment $(1.6 \%)$ which was due to the application of biochar only, followed by $\mathrm{T}_{14}$ $(1.41 \%)$. The lowest content of total carbon was observed in $\mathrm{T}_{8}$ (0.66). The available $\mathrm{P}$ in the soil of the current study varied from 182 to $3.55 \mathrm{ppm}$, with the highest value found in $\mathrm{T}_{12}(182 \mathrm{ppm})$, followed by $\mathrm{T}_{16}(103 \mathrm{ppm})$. The lowest available $\mathrm{P}$ was found in $\mathrm{T}_{1}$ (control). Mixing fertilizers with amendments enhanced soil available $\mathrm{P}$ in the soil. Use of amendments such as plant residue in combination with fertilizers acts as a source of nutrients and hence increases the availability of soil P to plants (Sabrina et al., 2013). In addition, organic matter from several amendments contains organic $\mathrm{P}$ and can be mineralized into inorganic forms (Guppy et al., 2005).

The control treatment reported the lowest CEC and exchangeable bases $(\mathrm{K}, \mathrm{Ca}, \mathrm{Mg}, \mathrm{Na})$. Treatment $\mathrm{T}_{14}$ treatment produced the highest $\mathrm{CEC}$, followed by $\mathrm{T}_{16}$. It showed that application of organic fertilizer in combination with amendments increased the CEC of the BRIS soils. Application of zeolite in combination with organic and inorganic fertilizers had also shown positive impact in terms of CEC. This result is comparable to that reported by Ahmed et al. (2010).

For $\mathrm{NH}_{4}^{+}$, the highest concentration (558.2985 ppm) was observed in $T_{15}$, while the lowest was detected in $T_{1}$. Too much nitrate in a soil is harmful for plant growth. According to Yang et al. (2005), mixing soil amendment with organic fertilizer is one method to reduce nitrate content in soil. Applying NPK together with zeolite can reduce nitrification process that slow down the $\mathrm{NH}_{4}{ }^{+}$ loss. This loss can also be reduced by applying NPK together with charcoal (Malisa et al., 2011). 
Table 2. The physio-chemical properties of BRIS Soils used in the experiment

\begin{tabular}{|c|c|}
\hline Soil properties & Content \\
\hline Sand $(\%)$ & 88.6800 \\
\hline Silt (\%) & 4.6800 \\
\hline Clay (\%) & 6.6400 \\
\hline pH (water) & 4.5400 \\
\hline $\mathrm{pH}(\mathrm{KCl})$ & 3.8400 \\
\hline Av. P (ppm) & 3.2000 \\
\hline Total N (\%) & 0.0300 \\
\hline Total C (\%) & 0.7600 \\
\hline CEC $\left(\mathrm{cmol}_{\mathrm{c}} \mathrm{kg}\right)$ & 2.6000 \\
\hline Exc. K ( $\left.\mathrm{cmol}_{\mathrm{c}} \mathrm{kg}\right)$ & 0.0300 \\
\hline Exc. $\mathrm{Ca}\left(\mathrm{cmol}_{\mathrm{c}} \mathrm{kg}\right)$ & 0.2300 \\
\hline Exc. $\mathrm{Mg}\left(\mathrm{cmol}_{\mathrm{c}} \mathrm{kg}\right)$ & 0.1700 \\
\hline Exc. $\mathrm{Na}\left(\mathrm{cmol}_{\mathrm{c}} \mathrm{kg}\right)$ & 0.0400 \\
\hline Exc. Al $\left(\mathrm{cmol}_{\mathrm{c}} \mathrm{kg}\right)$ & 1.1816 \\
\hline Exc. $\mathrm{NH}_{4}^{+}(\mathrm{ppm})$ & 23.8100 \\
\hline Exc. $\mathrm{NO}_{3}^{-}(\mathrm{ppm})$ & 28.0200 \\
\hline TOC (\%) & 0.4000 \\
\hline SOM (\%) & 1.2900 \\
\hline
\end{tabular}

Table 3. Selected soil chemical properties at harvest

\begin{tabular}{|c|c|c|c|c|c|c|c|c|c|c|c|c|c|}
\hline \multirow[b]{2}{*}{$\mathrm{T}$} & \multirow[b]{2}{*}{$\mathrm{pH}(\mathrm{w})$} & \multirow[b]{2}{*}{$\mathrm{pH}(\mathrm{K})$} & $\mathrm{T}-\mathrm{N}$ & $\mathrm{T}-\mathrm{C}$ & $\mathrm{CEC}$ & $\mathrm{K}$ & $\mathrm{Ca}$ & $\mathrm{Mg}$ & $\mathrm{Na}$ & $\mathrm{Al}$ & Av. P & $\mathrm{NH}_{4}^{+}$ & $\mathrm{NO}_{3}^{-}$ \\
\hline & & & \multicolumn{2}{|c|}{--------\%"------ } & \multicolumn{6}{|c|}{ 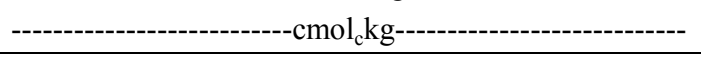 } & \multicolumn{3}{|c|}{-----------------ppm-------------- } \\
\hline $\mathrm{T}_{1}$ & 4.25 & 3.83 & 0.031 & 0.71 & 2.64 & 0.03 & 0.24 & 0.17 & 0.11 & 1.1816 & 3.55 & 23.82 & 28.020 \\
\hline $\mathrm{T}_{2}$ & 5.05 & 4.97 & 0.093 & 0.73 & 15.80 & 0.37 & 0.32 & 0.26 & 0.22 & 0.3223 & 97.30 & 377.60 & 231.170 \\
\hline $\mathrm{T}_{3}$ & 6.78 & 6.41 & 0.089 & 1.15 & 7.20 & 0.13 & 0.43 & 0.41 & 0.21 & 0.2148 & 14.10 & 42.03 & 51.137 \\
\hline $\mathrm{T}_{4}$ & 5.13 & 4.68 & 0.067 & 1.60 & 5.60 & 0.33 & 0.25 & 0.29 & 0.16 & 0.2148 & 5.63 & 23.82 & 21.716 \\
\hline $\mathrm{T}_{5}$ & 4.21 & 3.82 & 0.059 & 1.02 & 10.20 & 0.07 & 0.28 & 0.15 & 0.28 & 1.1816 & 3.92 & 28.72 & 30.122 \\
\hline $\mathrm{T}_{6}$ & 6.51 & 6.40 & 0.136 & 0.87 & 10.40 & 0.81 & 0.57 & 0.64 & 0.39 & 0.3223 & 81.40 & 121.20 & 143.600 \\
\hline $\mathrm{T}_{7}$ & 5.96 & 5.49 & 0.141 & 1.26 & 6.51 & 0.82 & 0.31 & 0.31 & 0.24 & 0.5371 & 107.00 & 114.90 & 105.780 \\
\hline $\mathrm{T}_{8}$ & 5.76 & 5.22 & 0.106 & 0.66 & 7.51 & 0.63 & 0.48 & 0.53 & 0.32 & 0.2148 & 93.10 & 253.60 & 240.970 \\
\hline $\mathrm{T}_{9}$ & 6.32 & 6.04 & 0.069 & 1.32 & 9.93 & 0.33 & 0.27 & 0.32 & 0.22 & 0.1074 & 9.09 & 43.43 & 35.726 \\
\hline $\mathrm{T}_{10}$ & 6.82 & 6.45 & 0.061 & 0.9 & 6.84 & 0.16 & 0.73 & 0.57 & 0.37 & 0.3223 & 10.10 & 34.32 & 29.421 \\
\hline $\mathrm{T}_{11}$ & 4.92 & 4.17 & 0.054 & 1.24 & 7.03 & 0.34 & 0.43 & 0.47 & 0.32 & 0.2148 & 4.84 & 23.82 & 26.619 \\
\hline $\mathrm{T}_{12}$ & 6.32 & 5.90 & 0.132 & 1.29 & 7.46 & 0.85 & 0.51 & 0.70 & 0.34 & 0.3223 & 182.00 & 135.90 & 197.540 \\
\hline $\mathrm{T}_{13}$ & 6.32 & 6.07 & 0.114 & 0.87 & 6.92 & 0.51 & 0.59 & 0.48 & 0.31 & 0.2148 & 88.80 & 121.90 & 79.857 \\
\hline $\mathrm{T}_{14}$ & 6.76 & 6.35 & 0.076 & 1.41 & 22.62 & 0.29 & 0.46 & 0.45 & 0.23 & 0.1074 & 8.14 & 39.93 & 30.822 \\
\hline $\mathrm{T}_{15}$ & 5.82 & 5.09 & 0.137 & 1.30 & 3.72 & 0.43 & 0.32 & 0.35 & 0.23 & 0.3223 & 89.60 & 558.30 & 95.268 \\
\hline $\mathrm{T}_{16}$ & 6.12 & 5.78 & 0.116 & 1.22 & 17.60 & 0.64 & 0.49 & 0.64 & 0.34 & 0.5371 & 103.00 & 160.40 & 186.330 \\
\hline
\end{tabular}

Note: $\mathrm{T}=$ Treatment, $\mathrm{w}=$ water, $\mathrm{K}=$ potassium chloride, $\mathrm{T}-\mathrm{N}=$ Total Nitrogen, $\mathrm{T}-\mathrm{C}=$ Total Carbon, Av. $\mathrm{P}=$ available phosphorus, $\mathrm{CEC}$ = Cation Exchange Capacity, $\mathrm{K}=$ exchangeable potassium, $\mathrm{Ca}=$ exchangeable calcium, $\mathrm{Mg}=$ exchangeable magnesium, $\mathrm{Na}=$ exchangeable sodium, $\mathrm{Al}=$ exchangeable aluminum, $\mathrm{NH}_{4}{ }^{+}=$exchangeable ammonium, $\mathrm{NO}_{3}{ }^{-}=$exchangeable nitrate, $\mathrm{ppm}=$ parts per million 
Mohd Hadi Akbar Basri et al. / American Journal of Applied Sciences 10 (12): 1586-1597, 2013

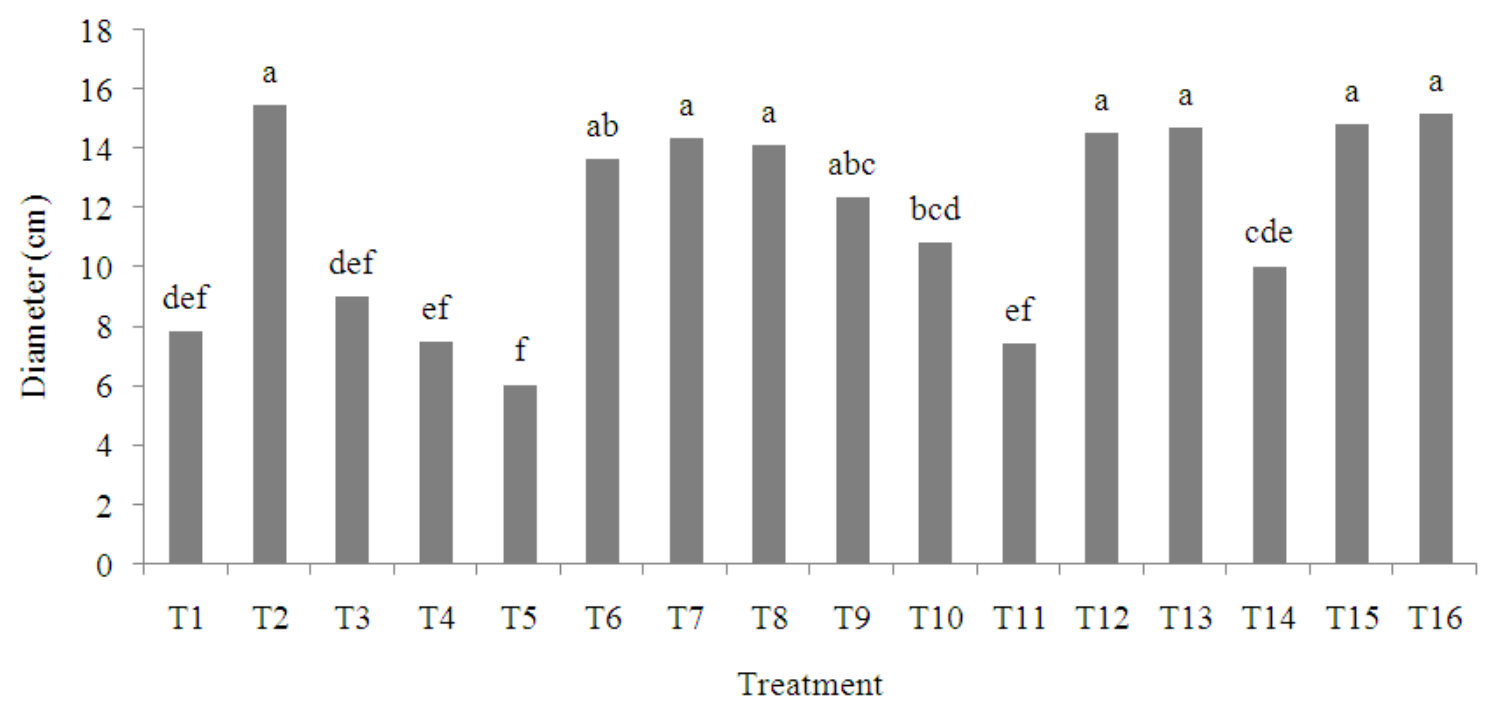

Fig. 1. Effect of treatments on diameter ofHibiscus cannabinus L. $\left(\mathrm{T}_{1}\right)$-control (100\% BRIS soil), $\left(\mathrm{T}_{2}\right)-\mathrm{NPK}$ (chemical fertilizer), $\left(\mathrm{T}_{3}\right)-$ chicken manure, $\left(T_{4}\right)$ - biochar, $\left(T_{5}\right)$ - zeolite, $\left(T_{6}\right)$ - NPK + chicken manure, $\left(T_{7}\right)$ - NPK + biochar, $\left(T_{8}\right)-$ NPK + zeolite, $\left(T_{9}\right)$ chicken manure + biochar, $\left(\mathrm{T}_{10}\right)$ - chicken manure + zeolite, $\left(\mathrm{T}_{11}\right)$ - biochar + zeolite, $\left(\mathrm{T}_{12}\right)$ - NPK + chicken manure + biochar, $\left(\mathrm{T}_{13}\right)$ - NPK + chicken manure + zeolite, $\left(\mathrm{T}_{14}\right)$ - chicken manure + biochar + zeolite, $\left(\mathrm{T}_{15}\right)$ - NPK + biochar + zeolite and $\left(\mathrm{T}_{16}\right)$ NPK + chicken manure + biochar + zeolite. Note: Means with the different letter are significantly different at $p \leq 0.05$ between treatments according to ANOVA and followed by a Duncan's Multiple Range Test (DMRT)

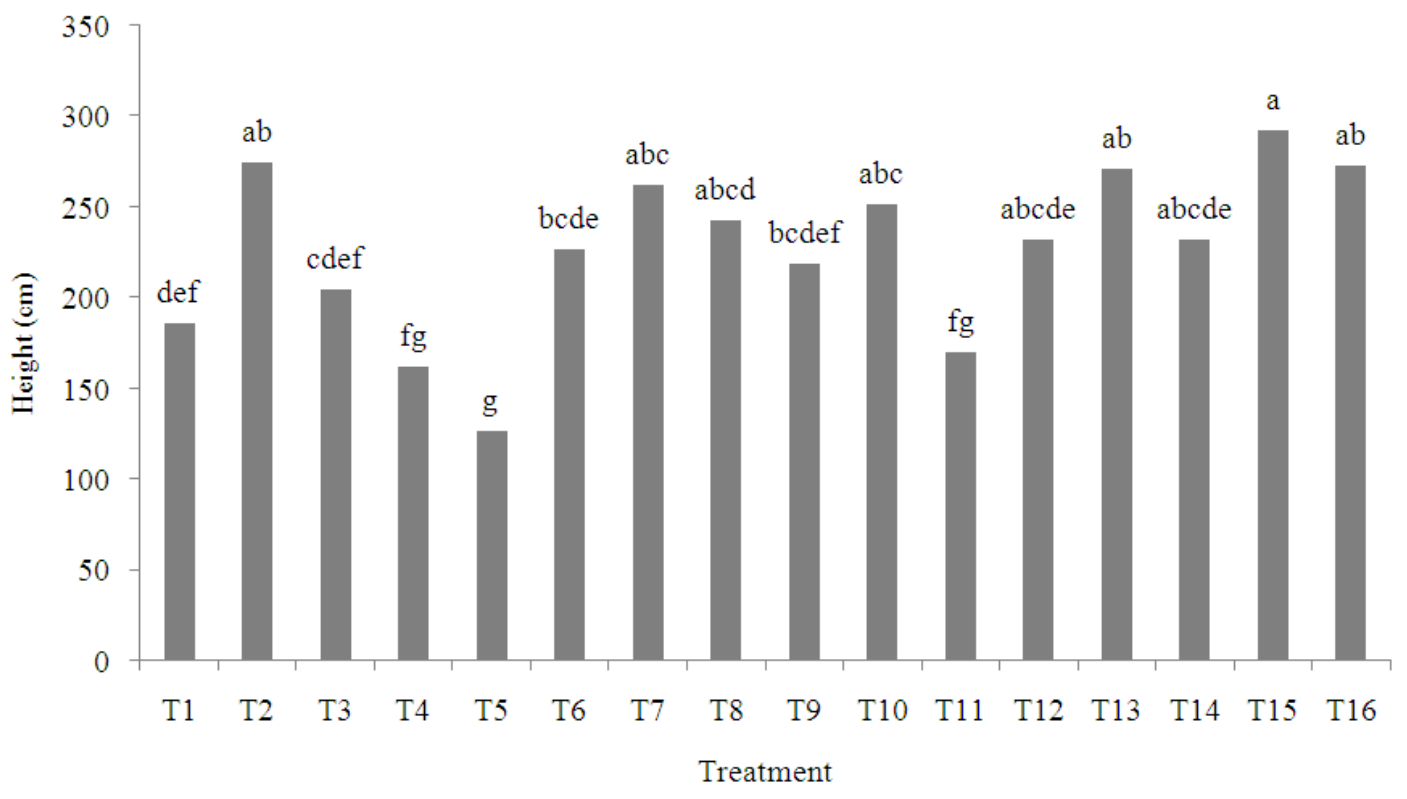

Fig. 2. Effect of treatments on height of Hibiscus cannabinus L. ( $\left.\mathrm{T}_{1}\right)$-control (100\% BRIS soil), $\left(\mathrm{T}_{2}\right)-\mathrm{NPK}$ (chemical fertilizer), $\left(T_{3}\right)$-chicken manure, $\left(T_{4}\right)$ - biochar, $\left(T_{5}\right)$ - zeolite, $\left(T_{6}\right)$ - NPK + chicken manure, $\left(T_{7}\right)$ - NPK + biochar, $\left(T_{8}\right)$ - NPK + zeolite, $\left(\mathrm{T}_{9}\right)$ - chicken manure + biochar, $\left(\mathrm{T}_{10}\right)$ - chicken manure + zeolite, $\left(\mathrm{T}_{11}\right)$ - biochar + zeolite, $\left(\mathrm{T}_{12}\right)-\mathrm{NPK}+$ chicken manure + biochar, $\left(\mathrm{T}_{13}\right)$-NPK + chicken manure + zeolite, $\left(\mathrm{T}_{14}\right)$ - chicken manure + biochar + zeolite, $\left(\mathrm{T}_{15}\right)-\mathrm{NPK}+$ biochar + zeolite and $\left(\mathrm{T}_{16}\right)$ - NPK + chicken manure + biochar + zeolite. Note: Means with the different letter are significantly different at $\mathrm{p} \leq 0.05$ between treatments according to ANOVA and followed by a Duncan's Multiple Range Test (DMRT) 


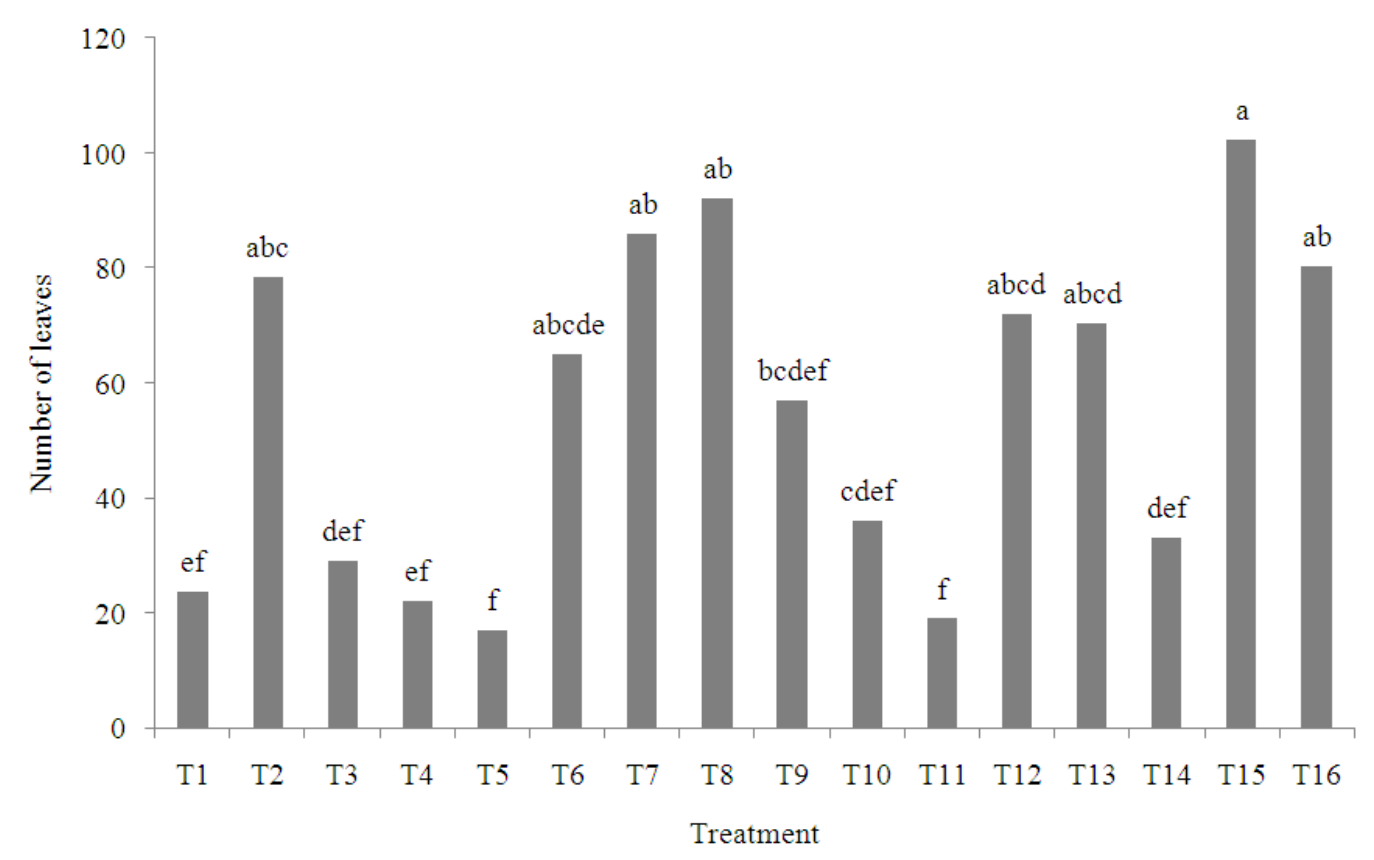

Fig. 3. Effect of treatments on number of leaves of Hibiscus cannabinus L. ( $\left.\mathrm{T}_{1}\right)$-control (100\% BRIS soil), ( $\left.\mathrm{T}_{2}\right)$-NPK (chemical fertilizer), $\left(\mathrm{T}_{3}\right)$-chicken manure, $\left(\mathrm{T}_{4}\right)$-biochar, $\left(\mathrm{T}_{5}\right)$ - zeolite, $\left(\mathrm{T}_{6}\right)$ - NPK + chicken manure, $\left(\mathrm{T}_{7}\right)$ - NPK + biochar, $\left(\mathrm{T}_{8}\right)$ - NPK + zeolite, $\left(\mathrm{T}_{9}\right)$ - chicken manure + biochar, $\left(\mathrm{T}_{10}\right)$ - chicken manure + zeolite, $\left(\mathrm{T}_{11}\right)$ - biochar + zeolite, $\left(\mathrm{T}_{12}\right)$ - NPK + chicken manure + biochar, $\left(\mathrm{T}_{13}\right)-\mathrm{NPK}+$ chicken manure + zeolite, $\left(\mathrm{T}_{14}\right)$ - chicken manure + biochar + zeolite, $\left(\mathrm{T}_{15}\right)-\mathrm{NPK}+$ biochar + zeolite and $\left(\mathrm{T}_{16}\right)-\mathrm{NPK}+$ chicken manure + biochar + zeolite. Note: Means with the different letter are significantly different at $\mathrm{p} \leq 0.05$ between treatments according to ANOVA and followed by a Duncan's Multiple Range Test (DMRT)

\subsection{Growth Performance of Kenaf}

The diameter of kenaf stem varied significantly $(\mathrm{p} \leq 0.05)$ due to different application rate or combination of organic and inorganic fertilizers (Fig. 1). Islam et al. (2011) stated that differences in combination of application of organic and chemical fertilizers significantly affected the growth and yield of plants, which supports the findings of this study. The diameter of kenaf stem in this study varied from $6.07 \mathrm{~mm}$ to 15.47 $\mathrm{mm}$, with the highest value observed in $\mathrm{T}_{2}(15.47 \mathrm{~mm})$. Diameter increment, in descending order, are: $\mathrm{T}_{2}(15.47$ $\mathrm{mm})>\mathrm{T}_{16}(15.18 \mathrm{~mm})>\mathrm{T}_{15}(14.83 \mathrm{~mm})>\mathrm{T}_{13}(14.742$ $\mathrm{mm})>\mathrm{T}_{12}(14.54 \mathrm{~mm})>\mathrm{T}_{7}(14.35 \mathrm{~mm})>\mathrm{T}_{8}(14.11 \mathrm{~mm})$ $>\mathrm{T}_{6}(13.65 \mathrm{~mm})>\mathrm{T}_{9}(12.37 \mathrm{~mm})>\mathrm{T}_{10}(10.83 \mathrm{~mm})>\mathrm{T}_{14}$ $(10.048 \mathrm{~mm})>\mathrm{T}_{3}(9.017 \mathrm{~mm})>\mathrm{T}_{1}(7.86 \mathrm{~mm})>\mathrm{T}_{4}(7.487$ $\mathrm{mm})>\mathrm{T}_{11}(7.44 \mathrm{~mm})>\mathrm{T}_{5}(6.07 \mathrm{~mm})$. Treatments with chemical fertilizer (NPK) showed the highest increment of diameter stem. These may be due to the plants receiving more readily available applied nutrients (NPK) in comparison with other treatments. Parraga et al. (1995) mentioned that application of organic matter with NPK fertilizer increased the diameter of root per plant.
Mixed fertilizer treatments resulted in higher stem diameter than the other treatments, which are consistent with the study of Srivastava et al. (2012). They reported that the combination of chemical fertilizer with organic materials significantly increased the number of leaves, diameter, fresh weight and leaf length.

It was observed that treatment $T_{5}$ showed lower basal diameter compared to that of treatment $T_{16}$. This shows that application of zeolite alone $\left(\mathrm{T}_{5}\right)$ does not help in kenaf growth. Treating BRIS Soils with zeolite in combination with organic and/or inorganic fertilizers produced contrasting results. Results from $\mathrm{T}_{16}, \mathrm{~T}_{15}, \mathrm{~T}_{14}$, $\mathrm{T}_{13}, \mathrm{~T}_{11}, \mathrm{~T}_{10}$ and $\mathrm{T}_{8}$ treatments were significantly different from that of $T_{5}$. These findingsare similar with those reported by Ahmed et al. (2010). Combining chemical fertilizer $\left(T_{7}\right)$ or chicken dung with biochar $\left(T_{9}\right)$ produced better result compared to single fertilizer application $\left(\mathrm{T}_{3}\right.$ and $\mathrm{T}_{4}$ ). If this finding is adopted by farmers in the BRIS Soils areas, the use of chemical fertilizers can be somewhat minimized, maintaining environmental conditions. Combining chicken manure with chemical fertilizer may inhibit the growth of kenaf 
compared than chemical fertilizer alone because of the presence of excessive soluble salts (or salinity) supplied by chicken manure. This is consistent with the study conducted by Stephenson et al. (1990) who stated that high electrical conductivity caused by excessive application of chicken manure increased salinity in soils which consequently affected plant growth. Although some studies revealed that the temperature of the greenhouse also affected the salt concentration in the soils (Sun and Chen, 1992). From this study, its means that the mixture of chicken manure and NPK fertilizers should not be applied on BRIS soils. However, with a suitable and appropriate ratio of chicken manure and lower chemical fertilizer applied, the yield will be similar to application of chemical fertilizer alone. Hence, the use of chemical fertilizer may be minimized. Boateng et al. (2006) found in their study stated that low rate of chemical fertilizer and suitable amount of poultry manure increase the grain yield. This is because of the complementary and synergistic effects of the organic and inorganic fertilizers. Other study conducted by Magid et al. (1995) also suggested that application of chicken manure beyond a certain amount resulted in decreasing of grain yield. Hence, it is recommended more studies should be carried out in order to obtain the best method and application rate for mixing the chicken manure with chemical fertilizer on BRIS soil in Malaysia.

The height of kenaf recorded in this study was in the range of 126.89 to $292.22 \mathrm{~cm}$ (Fig. 2). The highest height increment was recorded in treatments $T_{15}$ and the lowest height was in $T_{5}$. This result indicates that application of biochar in combination with chicken dung gave lower height increment as compared with the fertilizer plus organic material treatment. Zhou et al. (2002) reported that plants grown on soil streated with chemical fertilizer together with organic manure grew quite well by adjusting nutrients released into the soil. $\mathrm{Xu}$ et al. (2008) also supported that combining the chemical fertilizer with organic manure gave a better yield of crops due to the increasing of soil organic matter, improved soil function, decreased the nitrate in soil and increased the soil buffering capacity.

The height of kenaf due to treatment is ranked in the following orders: $\mathrm{T}_{15}(292.22 \mathrm{~cm})>\mathrm{T}_{2}(274.78 \mathrm{~cm})>\mathrm{T}_{16}$ $\left(\begin{array}{llll}272.78 & \mathrm{~cm}\end{array}\right)>\mathrm{T}_{13} \quad(271.11 \mathrm{~cm})>\mathrm{T}_{7} \quad(261.89 \mathrm{~cm})>\mathrm{T}_{10}$ $(251.56 \mathrm{~cm})>\mathrm{T}_{8} \quad(243.11 \mathrm{~cm})>\mathrm{T}_{12} \quad(232.43 \mathrm{~cm})>\mathrm{T}_{14}>$ $(232.22 \mathrm{~cm})>\mathrm{T}_{6}(226.89 \mathrm{~cm})>\mathrm{T}_{9}(219.11 \mathrm{~cm})>\mathrm{T}_{3}(204.28$ $\mathrm{cm})>\mathrm{T}_{1}(186.33 \mathrm{~cm})>\mathrm{T}_{11}(170.39 \mathrm{~cm})>\mathrm{T}_{4}(161.94 \mathrm{~cm})$ $>\mathrm{T}_{5}(126.89 \mathrm{~cm})$. This study showed that the highest value was observed in treatment $\mathrm{T}_{15}$, reaching almost $3 \mathrm{~m}$ in height. The total height recorded was lower than 3 probably because of high temperature in the glasshouse with in a range of $23^{\circ} \mathrm{C}$ and $38^{\circ} \mathrm{C}$. This is similar reported by Roslan et al. (2011), high average temperatures up to $28^{\circ} \mathrm{C}$ seriously affected kenaf height. Figure 2 shows that the Kenaf height in treatment $\mathrm{T}_{7}$ was significantly higher than the treatment in $\mathrm{T}_{6}$. The highest height value recorded in $T_{15}$ may be due to the properties of the mixture. $T_{15}$ consists of chemical fertilizer, organic material (biochar) and secondary minerals (zeolite). Biochar having the ability to retain nutrients, reduce nutrient leaching, improving soil quality and carbon sequestration, hence even supplying nutrients to plants (Lehmann and Joseph, 2009; Glaser et al., 2002). Hence, amending soil with biochar may increase plant growth and crop yields (Rondon et al., 2007; Graber et al., 2010). Furthermore, zeolites enable both organic and inorganic fertilizers slowly release their nutrients (PerezCaballero et al., 2008). Hence, application of zeolite functions as an excellent carrier and as a good source to supply plant nutrients such as $\mathrm{K}, \mathrm{Ca}$ and $\mathrm{Mg}$ (Bagdasarov et al., 2004). With the combination of zeolite and chemical fertilizer, may increase the properties and indirectly improve the poor soil. Research conducted by Supapron et al. (2002) found that combination of chemical fertilizer with zeolite improved soil chemical properties, sugarcane growth and yield. Mixing Zeolite with chemical fertilizer also plays an important role to control ammonia loss and enhance the nutrient efficiency (Leggo, 2000; Latifah et al., 2011). However, from this study revealed that application of zeolite alone, $\mathrm{T}_{5}$ gave the lowest yield as compared than mixed treatment due to the acidic condition and not suitable for plant growth. This result was similar reported by (Burriesci et al., 1984; Dwairi, 1998) in their studies who stated that zeolite cannot be fully substituted with fertilizer and should be mixed with other fertilizer in order to obtained a positive crop yield.

The maximum number of leaves was recorded in $\mathrm{T}_{15}$ (102.33), followed by $\mathrm{T}_{8}(92.00), \mathrm{T}_{7}(86.00), \mathrm{T}_{16}(80.33)$, $\mathrm{T}_{2}$ (78.33), $\mathrm{T}_{12}(72.00), \mathrm{T}_{13}(70.33), \mathrm{T}_{6}(65.00), \mathrm{T}_{9}(57.00)$, $\mathrm{T}_{10}$ (36.00), $\mathrm{T}_{14}(33.00), \mathrm{T}_{3}(29.00), \mathrm{T}_{1}(23.67), \mathrm{T}_{4}(22.00)$ and $T_{11}$ (19.00) (Fig. 3). The combined NPK and organic fertilizer treatment resulted in higher number of leaves as compared to organic fertilizer treatment. Xu et al. (2008) also reported that application of single fertilizer gave a poorer result as compared to mixed fertilizer. In the case of mixed fertilizer treatment, $\mathrm{T}_{15}$ obtained higher number of leaves, which may be due to the properties applied in the mixture. A combination between NPK, biochar and zeolite not just give a best yield in term of height, but relatively affected the number of leaves produced by kenaf. From 
this study, $\mathrm{T}_{15}$ shows the highest ranking for both height and number of leaves respectively. This was similar to a research reported by Hossain et al. (2012) who found a positive a relationship between plant height and the number of leaves of kenaf grown on sandy soil. The number of leaves influence the total leaf area, which was important in determine the photosynthesis rate ( $\mathrm{Li}$ et al., 2009). Studies by Ogbonnaya et al. (1998) also describe how well the functions of leaf photosynthesis in order to get a necessary carbohydrate that were importance for plant growth.

\section{CONCLUSION}

Application of organic fertilizer in combination with chemical fertilizer (NPK) had significant effects on the growth of kenaf. The highest height increment and number of leaves for kenaf in this study was recorded in $\mathrm{T} 15$, followed by treatment $\mathrm{T}_{2}$ and $\mathrm{T}_{16}$. The highest diameter was obtained in $T_{2}$, followed by $T_{15}$ and $T_{16}$. The fertility of the BRIS Soils was significantly improved due to treatment of fertilizers in combination with amendment. The highest total $\mathrm{N}(0.14 \%)$ was found in $\mathrm{T}_{7}$, while the untreated soil contained only $0.04 \%$ total N. Treatments 15 (NPK + Biochar + Zeolite) showed better result in terms of growth performance although total $\mathrm{N}$ content in the soil was lower than other treatments. It seemed that the improvement of the fertility of BRIS soils in Malaysia can be achieved by applying a suitable combination of fertilizers mixed with biochar or zeolite.

\section{ACKNOWLEDGEMENT}

The researchers are grateful to the staff Department of Forest Management, Faculty of Forestry, Institute of Tropical Forestry and Forest Products, University Putra Malaysia for assisting during site preparation and laboratory analysis. This study was financially supported by the Ministry of Higher Education (MOHE) under Fundamental Research Grant Scheme (FRGS) and Research University Grant Scheme (RUGS) through Universiti Putra Malaysia (UPM).

\section{REFERENCES}

Abdul-Hamid, H., M.H. Yusoff, N.A. Ab-Shukor, B. Zainal and M.H. Musa, 2009. Effects of different fertilizer application level on growth and physiology of Hibiscus Cannabinus L. (Kenaf) planted on BRIS soil. J. Agric. Sci., 1: 121-131.
Ahmed, O.H., G. Sumalatha and A.M.N. Muhamad, 2010. Use of zeolite in maize (Zea mays) cultivation on nitrogen, potassium and phosphorus uptake and use efficiency. Int. J. Phys. Sci., 5: 2393-2401.

Ahmed, O.H., H. Aminuddin, M.H.A. Husni, A.R. Anuar and N.M.A. Majid, 2008. Enhancing the urea-n use efficiency in maize (zea mays) cultivation on acid soils amended with zeolite and TSP. Sci. World J., 8: 394-399. DOI: 10.1100/tsw.2008.68

Akbar, M.H., O.H. Ahmed, A.S. Jamaluddin, N.M. Majid and H. Abdul-Hamid et al., 2010. Differences in soil physical and chemical properties of rehabilitated and secondary forests. Am. J. Applied $\begin{array}{lll}\text { Sci., } & \text { 7: } & \text { 1200-1209. }\end{array}$ 10.3844/ajassp.2010.1200.1209.

Almodeares, A., R. Taheri, I.M. Chung and M. Fathi, 2008. The effect of nitrogen and potassium fertilizers on growth parameters and carbohydrate contents of sweet sorghum cultivars. J. Environ. Biol., 29: 849-852. PMID: 19297978

Arifin, A., S. Tanaka, S. Jusop, N.M. Majid and Z. Ibrahim et al., 2008. Assessment on soil fertility status and growth performance of planted dipterocarp species in Perak, Peninsular Malaysia. J. Applied Sci., 8: 3795-3805.

Bagdasarov, V.R., A.A. Kazachencko, M.K. Rustambekov, B.G. Uspenskij and V.V. Kuznetsova et al., 2004. Prolonged-activity nitrogen-zeolite fertilizer. Russia.

Boateng, S.A., J. Zickermann and M. Kornahrens, 2006. Poultry manure effect on growth and yield of maize. West Afr. J. Applied Ecol., 9: 1-11.

Bray, R.H. and L.T. Kurtz, 1945. Determination of total, organic and available forms of phosphorus in soils. Soil Sci., 59: 39-45. DOI: 10.1097/00010694194501000-00006

Burriesci, N., S. Valente, C. Zipelli and J.C.J. Bart, 1984. Studies on zeolites in agriculture. Effect on crop growth of Prunus persica and Vifis vinifera. Zeolites, 4: 373-376. DOI: 10.1016/01442449(84)90014-9

Camberato, J. and C. Mitchell, 2011. Liming value of poultry manures.

Chen, C.P., 1985. The Research and Development of Pastures in Peninsular Malaysia. In: Pastures in the Tropics and Subtropics, Andriesse, J.P. (Ed.), Tsukuba, Japan, pp: 33-51. 
Day, P.R., 1965. Particle Size Fractionation and Particle Size Analysis. In: Methods of Soil Analysis, Black, C.A.M. (Ed.). Wisc, American SocAgron, pp: 545567.

Dharejo, K.A., A.R. Anuar, N. Junejo, Y.M. Khanif and A.W. Samsuri, 2012. Effects of four depths of spodic horizon on root morphology and nutrient partitioning of kenaf grown on sandy beach ridge soil. Sci. Res. Essays, 7: 2277-2283.

Dikinya, O. and N. Mufwanzala, 2010. Chicken manureenhanced soil fertility and productivity: Effects of application rates. J. Soil Sc. Environ. Manage., 1: 46-54.

Duncan, J., 2005. Composting chicken manure. WSU Cooperative Extension, King County Master Gardener and Cooperative Extension Livestock Advisor.

Dwairi, I.M., 1998. Renewable, controlled and environmentally safe phosphorus release in soils from mixtures of $\mathrm{NH}_{4}{ }^{+}$-phillipsite tuff and phosphate rocks. Environ. Geol., 34: 293-296. DOI: 10.1007/s002540050280

Glaser, B., J. Lehmann and W. Zech, 2002. Ameliorating physical and chemical properties of highly weathered soils in the tropics with charcoal-a review. Biol. Fert. Soils, 35: 219-230. DOI: 10.1007/s00374-002-0466-4

Glisig, I.P., T.M. Milosevic, I.S. Glisic and N.T. Milosevic, 2008. The effect of natural zeolites and organic fertilisers on the characteristics of degraded soils and yield of crops grown in Western Serbia. Land Degradat. Dev., 20: 33-40. DOI: 10.1002/1dr.875

Graber, E.R., Y.M. Harel, M. Kolton, E. Cytryn and A. Silber et al., 2010. Biochar impact on development and productivity of pepper and tomato grown in fertigated soilless media. Plant Soil, 337: 481-496. DOI: $10.1007 / \mathrm{s} 11104-010-0544-6$

Guppy, C.N., N.W. Menzies, P.W. Moody and F.P.C. Blamey, 2005. Competitive sorption reactions between phosphorus and organic matter in soil: A review. Soil Res., 43: 189-202. DOI: 10.1071/SR04049

Hamzah, M.Z., A. Arifin, A.K. Zaidey, A.N. Azirim and I. Zahari et al., 2009. Characterizing soil nutrient status and growth performance of planted dipterocap and non-dipterocarp species on degraded forest land in Peninsular Malaysia. J. Applied Sci., 9: 42154223.
Hanafi, M.M., S.M. Shahidullah, M. Niazuddin, Z. Abd Aziz and C.H. Mohammud, 2010. Potential use of sea water for pineapple production in BRIS soil. Int. J. Agric. Biol., 12: 396-400.

Hecl, J. and S. Toth, 2009. Effect of fertilizers and sorbents applied to the soil on heavy metal transfer from the soil. Electron. J. Polish Agric. Univ., 12: 717.

Hossain, M.D., M.M. Hanafi, G. Saleh, M. Foroughi and R. Behmaram et al., 2012. Growth, photosynthesis and biomass allocation of different kenaf ('Hibiscus cannabinus' L.) accessions grown on sandy soil. Aus. J. Crop Sci., 6: 480-487.

Islam, M.M., A.J.M.S., Karim, M. Jahiruddin, N.M. Majid and M.G. Miah et al., 2011. Effects of organic manure and chemical fertilizers on crops in the radish-stem amaranth-Indian spinach cropping pattern in homestead area. Aus. J. C. Sci., 5: 13701378.

Jones, Jr. J.B., 2001. Laboratory Guide for Conducting Soil Tests and Plant Analysis. 1st Edn., CRC Press, ISBN-10: 0849302064, pp: 384.

Keeney, D.R. and D.W. Nelson, 1982. NitrogenInorganic Forms. In: Methodsof Soil Analysis, Page, A.L., D.R. Keeney, D.E. Baker, R.H. Miller and R. Ellis Jr. et al. (Eds.), Agron, Monogr, ASA and SSSA, Madison, WI.

Latifah, O., O.H. Ahmed and A.M. N. Muhamad, 2011. Ammonia loss, ammonium and nitrate accumulation from mixing urea with zeolite and peat soil water under waterlogged condition. Afr. J. Biotechnol., 10: 3365-3369.

Lavkulich, L.M., 1981. Method Manual, Pedology Laboratory. Department of Soil Science, University of British Columbia, Vancouver, British Columbia, Canada.

Leggo, P.J., 2000. An investigation of plant growth in an organo-zeolitic substrate and its ecological significance. Plant Soil, 219: 135-146. DOI: 10.1023/A:1004744612234

Lehmann, J. and S. Joseph, 2009. Biochar for Environmental Management: Science and Technology. 1st Edn., Routledge, ISBN-10: 184407658X, pp: 448.

Lehmann, J., J.P. Da Silva Jr., C. Steiner, T. Nehls and W. Zech et al., 2003. Nutrient availability and leaching in an archaeological Anthrosol and a Ferralsol of the Central Amazon basin: Fertilizer, manure and charcoal amendments. Plant Soil, 249: 343-357. DOI: 10.1023/A:1022833116184 
Li, F.L., W.K. Bao and N. Wu, 2009. Effects of water stress on growth, dry matter allocation and wateruse efficiency of a leguminous species, Sophora davidii. Agroforest Syst., 77: 193-201. DOI: 10.1007/s10457-008-9199-1

Magid, H.M.A., S.I. Abdel-Aal, R.K. Rabie and R.E.A. Sabrah, 1995. Chicken manure as a biofertilizer for wheatin the sandy soils of Saudi Arabia. J. Arid Environ., 29: 413-420. DOI: 10.1016/S01401963(05)80119-3

Major, J., J. Lehmann, M. Rondon and C. Goodale, 2010. Fate of soil-applied black carbon: Downward migration, leaching and soil respiration. Global Change Biol., 16: 1366-1379. DOI: 10.1111/j.13652486.2009.02044.x

Malisa, M.N., J., Hamdan and M.H.A. Husni, 2011. Yield Response of Kenaf (Hibiscus Cannabinus L.) to different rates of charcoal and nitrogen fertilizer on bris soils in Malaysia. Middle-East J. Scien. Res., 10: 54-59.

Ming, D.W. and J.B. Dixon, 1986. Clinoptilolite in South Texas soils. Soil Sci. Soc. Am. J., 50: 16181622.

DOI: 10.2136/sssaj1986.03615995005000060047x

Mumpton, F.A., 1999. La roca magica: Uses of natural zeolites in agriculture and industry. Proc. Natl. Acad. Sci. USA., 96: 3463-3470. DOI: 10.1073/pnas.96.7.3463

Ogbonnaya, C.I., M.C. Nwalozie, H. Roy-Macauley and D.J.M. Annerose, 1998. Growth and water relations of Kenaf (Hibiscus cannabinus L.) under water deficit on a sandy soil. Indus. Crops Product., 8: 6576. DOI: 10.1016/S0926-6690(97)10011-5

Ohta, S. and S. Effendi, 1992. Ultisols of "lowland Dipterocarp forest" in East Kalimantan, Indonesia: II. Status of carbon, nitrogen, and phosphorus. Soil Sci. Plant Nutr., 38: 197-206. DOI: 10.1080/00380768.1992.10416483

Parfitt, R.L., D.J. Giltrap and J.S. Whitton, 1995. Contribution of organic matter and clay minerals to the cation exchange capacity of soils. Commun. Soil Sci. Plant Anal., 26: 1343-1355. DOI: 10.1080/00103629509369376

Parraga, M.S., A.L. Pereira, J.L. Medeiros and P.F.P. Carvalho, 1995. Effect of organic matter on quantity and quality of roots in carrot (Daucuscarrota L.) harvested at three dates. Semira (Londrina), 16: 80-85.
Perez-Caballero, R., J. Gill, C. Benitez and J.L. Gonzalez, 2008. The effect of adding zeolite to soils in order to improve the N-K nutrition of olive trees, preliminary results. Am. J. Agric. Biol. Sci., 2: 321-324. DOI: 10.3844/ajabssp.2008.321.324

Preston, S., 2003. Kenaf Production. NCAT Agriculture Specialist.

Rondon, M.A., J. Lehmann, J. Ramirez and M. Hurtado, 2007. Biological nitrogen fixation by common beans (Phaseolus vulgaris L.) increases with bio-char additions. Biol. Fertility Soils, 43: 699-708. DOI: 10.1007/s00374-006-0152-z

Roslan, I., J. Shamshuddin, C.I. Fauziah and A.R. Anuar, 2010. Occurrence and properties of soils on sandy beach ridges in the Kelantan-Terengganu Plains, Peninsular Malaysia. CATENA, 83: 55-63. DOI: 10.1016/j.catena.2010.07.004

Roslan, I., J. Shamshuddin, C.I. Fauziah and A.R. Anuar, 2011. Fertility and suitability of the spodosols formed on sandy beach ridges interspersed with swales in the Kelantan-Terengganu Plains of Malaysia for kenaf production. Malaysian J. Soil Sci., 15: 1-24.

Sabrina, D.T., M.M. Hanafi, A.W. Gandahi, M.T.M. Mohamed and N.A.A. Aziz, 2013. Effect of mixed organic-inorganic fertilizer on growth and phosphorus uptake of setaria grass (Setaria splendida). Aust. J. Crop Sci., 7: 75-83.

Saga, B.T., O.H. Ahmed, A.S. Jamaluddin, H. AbdulHamid and S. Jusop et al., 2010. Selected soil morphological, mineralogical and sesquioxide properties of rehabilitated and secondary forests. Am. J. Environ. Sci., 6: 389-394. DOI: 10.3844/ajessp.2010.389.394

Sakurai, K., S. Tanaka, S. Ishizuka and M. Kanzaki. 1998. Dlfferences in soil properties of dry evergreen and dry deciduous forests in the sakaerat environmental research station. Tropics, 8: 61-80. DOI: $10.3759 /$ tropics.8.61

SAS, 2001.SAS/STAT Software. SAS Institute, Cary, Inc. Srivastava, P.K., M. Gupta, R.K. Upadhyay, S. Sharma and Shikha et al., 2012. Effects of combined application of vermicompost and mineral fertilizer on the growth of Allium cepa L. and soil fertility. J. Plant Nutr. Soil Sci., 175: 101-107. DOI: 10.1002/jpln.201000390 
Steiner, C., B. Glaser, W.G. Teixera, J. Lehmann and W.E.H. Blum et al., 2008. Nitrogen retention and plant uptake on a highly weathered central Amazonian Ferralsol amended with compost and charcoal. J. Plant Nutr. Soil Sci., 171: 893-899. DOI: 10.1002/jpln.200625199

Stephenson, A.H., A.T. McCaskey and B.G. Ruffin, 1990. A survey of broiler litter composition and potential value as a nutrient resource. Biol. Wastes, 34: 1-9. DOI: 10.1016/0269-7483(90)90139-J

Sumner, M.E. and B.A. Stewart, 1992. Soil Crusting Chemical and Physical Processes. 1st Edn., CRC Press, ISBN-10: 0873718690, pp: 384.

Sun, F. and J.Z. Chen, 1992. Secondary salinization in greenhouse. J. Shanghai Agric. College, 10: 132140.

Supapron, J., L. Pitayakon, W. Kamalapa and P. Touchamon, 2002. Effect of zeolite and chemical fertilizer on the change of physical and chemical properties on Lat Ya soil series for sugar cane. Proceedings of the 17th WCSS Symposium, Aug. 14-21, Thailand.

Taghizadeh-Toshi, A., T.J., Clough, R.R. Sherlock and L.M. Condron, 2012. Biochar adsorbed ammonia is bioavailable. Plant Soil, 350: 57-69. DOI: 10.1007/s11104-011-0870-3

Terbe, I., 2004. Some relationships between soil and nutrient requirements and nutrient supply of pepper (Capsicum annuиm L.) with respect to types grown in Hungary. Int. J. Horticul. Sci. Hungary, 10: 93105.

Toriman, M.E.H., M.B. Mokhtar, M.B. Gazim and N.A.A. Aziz, 2009. Analysis of the physical characteristics of bris soil in Coastal Kuala Kemaman, Terengganu. Res. J. Earth Sci., 1: 1-6.
Warman, P.R., 1986. The effect of fertilizer, chicken manure and dairy manure on Timothy yield, tissue composition and soil fertility. Agric. Wastes, 18: 289-298. DOI: 10.1016/0141-4607(86)90074-0

$\mathrm{Xu}$, M., D. Li, J. Mei, D. Qin and Y. Kazuyuki et al., 2008. Effects of organic manure application with chemical fertilizers on nutrient absorption and yield of rice in Hunan of Southern China. Agric. Sci. China, 7: 1245-1252. DOI: 10.1016/S16712927(08)60171-6

Yang, S.M., F.M. Li, D.R. Suo, T.W. Guo and J.G. Wang et al., 2005. Effect of long-term fertilization on soil productivity and nitrate accumulation in gansu oasis. Sci. Agric. Sinica, 38: 2043-2052.

Zaidey, A.K., A. Arifin, I. Zahari, A.H. Hazandy and M.H. Zaki et al., 2010. Characterizing soil properties of lowland and hill dipterocarp forests at Peninsular Malaysia. Int. J. Soil Sci., 5: 112-130. DOI: 10.3923/ijss.2010.112.130

Zheng, H., Z. Wang, X. Deng, S. Herbert and B. Xing, 2013. Impacts of adding biochar on nitrogen retention and bioavailability in agricultural soil. Geoderma 206: 32-39. DOI: 10.1016/j.geoderma.2013.04.018

Zhou, W.J., K.R. Wang, G.Y. Zhang and X.L. Xie, 2002. Effects of inorganic-organic fertilizer incorporation on productivity and soil fertility of rice cropping system in red soil area of China. Sci. Agric. Sinica, 35: 1109-1113. 